\title{
Perspectives on carbon materials as powerful catalysts in continuous anaerobic bioreactors
}

\author{
R.A. Pereira a , A.F. Salvador ${ }^{\text {a }}$, P. Dias ${ }^{\text {a }}$, M.F.R. Pereira ${ }^{\text {b }}$, M.M. Alves a , L. Pereira ${ }^{\text {a, * }}$ \\ ${ }^{a}$ Centro de Engenharia Biológica, Universidade do Minho, Campus de Gualtar, 4710-057 Braga, Portugal \\ ${ }^{\mathrm{b}}$ Laboratório de Catálise e Materiais (LCM), Laboratório Associado LSRE/LCM, Departamento de Engenharia Química, Faculdade Engenharia da \\ Universidade do Porto, Rua Dr. Roberto Frias, 4200-465 Porto, Portugal
}

\section{A R T I C L E I N F O}

\section{Article history:}

Received 17 March 2016

Received in revised form 16 May 2016

Accepted 2 June 2016

Available online 4 June 2016

\section{Keywords:}

Anaerobic bioreduction

Carbon materials

Microbial diversity

Redox mediators

UASB bioreactor

\begin{abstract}
A B S T R A C T
The catalytic effect of commercial microporous activated carbon (AC) and macroporous carbon nanotubes (CNT) is investigated in reductive bioreactions in continuous high rate anaerobic reactors, using the azo dye Acid Orange 10 (AO10) as model compound as electron acceptor and a mixture of VFA as electron donor. Size and concentration of carbon materials (CM) and hydraulic retention time (HRT) are assessed. $\mathrm{CM}$ increased the biological reduction rate of AO10, resulting in significantly higher colour removal, as compared to the control reactors. The highest efficiency, $98 \%$, was achieved with a CNT diameter (d) lower than $0.25 \mathrm{~mm}$, at a CNT concentration of $0.12 \mathrm{~g}$ per $\mathrm{g}$ of volatile solids (VS), a HRT of $10 \mathrm{~h}$ and resulted in a chemical oxygen demand (COD) removal of $85 \%$. Reducing the HRT to $5 \mathrm{~h}$, colour and COD removal in CM-mediated bioreactors were above $90 \%$ and $80 \%$, respectively. In the control reactor, thought similar COD removal was achieved, AO10 decolourisation was just approximately 20\%, demonstrating the ability of CM to significantly accelerate the reduction reactions in continuous bioreactors. AO10 reduction to the correspondent aromatic amines was proved by high performance liquid chromatography (HPLC). Colour decrease in the reactor treating a real effluent with CNT was the double comparatively to the reactor operated without CNT. The presence of AC in the reactor did not affect the microbial diversity, as compared to the control reactor, evidencing that the efficient reduction of AO10 was mainly due to AC rather than attributed to changes in the composition of the microbial communities.
\end{abstract}

() 2016 Elsevier Ltd. All rights reserved.

\section{Introduction}

Carbon materials have a versatile and powerful role in the field of environmental biotechnology. Activated carbon is available in granular and powder forms, but also as felts, fibres, clothes, or monoliths. It has been widespread applied as pollutant adsorbent (Marsh and Rodríguez-Reinoso, 2006), as support for biofilm formation (Herzberg et al., 2004), in activated sludge processes (Shaul et al., 1983; Specchia and Gianetto, 1984), and also inducing microbial shifts in anaerobic processes, apparently by promoting the growth of electroactive bacteria (Liu et al., 2012). The use of tailored $\mathrm{CM}$ in electrodes of bioelectrical systems is also an emerging field where these materials influence the rate of current production (Xie et al., 2015).

The use of CM as redox mediator (RM) in biological and chemical

\footnotetext{
* Corresponding author.

E-mail address: lucianapereira@deb.uminho.pt (L. Pereira).
}

reactions has been deserved growing importance in the field of environmental bio/technology. RM are soluble compounds or insoluble materials that accelerate the electron transfer from an electron donor to an electron acceptor in multiple redox reactions (Van der Zee and Cervantes, 2009). RM have the capacity to minimize the steric hindrance of the molecules and to decrease the activation energy of the reduction reaction, thus acting as catalysts (Bragger et al., 1997; Moir et al., 2001). Compared with soluble RM, insoluble materials such as CM have the advantage of being retained inside the reactors, avoiding the need to be fed continuously, and thus decreasing the operating costs. Being continuously reduced and oxidised, these materials are self-regenerated and only a small amount is necessary to achieve a significant improvement in process performance.

The use of CM as RM has been reported in several studies of dyes decolourisation (e.g. Van der Zee et al., 2003; Pereira et al., 2010; 2014; Mezohegyi et al., 2007, 2008, 2010), and reduction of nitrocompounds (Amezquita-Garcia et al., 2013, 2016; Colunga et al., 2015; Pereira et al., 2016). 
In previous batch experiments at our laboratory, the capacity of different CM as RM on chemical (using sodium sulfide) and biological reduction of azo dyes (Pereira et al., 2010, 2014) and of nitroanilines (Pereira et al., 2016) was demonstrated, increasing the reduction rates of azo dyes up to 9-fold and of nitroanilines up to 8fold. Among the tested materials, the best results for azo dyes were obtained with the macroporous CNT, due to the easier access of the azo dye molecules to the internal surface. For nitroanilines, smaller molecules, AC was preferential.

The purpose of the present work is to evaluate the performance of different $\mathrm{CM}$ as RM on the biological reduction reactions in continuous Upflow Anaerobic Sludge Blanket (UASB) reactors. These reactors are able to retain high concentrations of settling granular biomass with high specific activity and thereby can achieve good COD removal efficiency at high organic loading rates (Lettinga et al., 1980). When treating compounds with electrophilic groups such as azo-dyes or nitrocompounds, the rate of reduction can be increased by amending the sludge blanket with small concentrations of insoluble RM. AO10 was chosen as model compound due to its recalcitrant nature as previously found in batch assays (Pereira et al., 2014). In order to optimize the process, different parameters were studied: type of $\mathrm{CM}$ ( $\mathrm{AC}$ and $\mathrm{CNT})$, concentration of $\mathrm{CM}\left(0.6\right.$ and $\left.1.2 \mathrm{~g} \mathrm{~L}^{-1}\right)$, size of CM (from 0.6 to $0.25 \mathrm{~mm}$ ) and HRT $(20,10$ and $5 \mathrm{~h})$. CNT were also tested in a bioreactor treating an industrial textile effluent. This is the first report on the application of CNT as RM for the biological reduction of azo dyes and industrial effluents, in continuous reactors. The amount of $\mathrm{CM}$ used is circa 8 to 80 times lower than the quantity used by other authors. Because the presence of AC was suggested to induce changes in the microbial diversity of anaerobic sludge (Liu et al., 2012), the effect of the presence of $\mathrm{CM}$ on the microbial community present in the UASB reactors was also investigated.

\section{Materials and methods}

\subsection{Carbon materials and chemicals}

The CM tested were a commercial AC (NORIT ROX0.8, pellets of $0.8 \mathrm{~mm}$ diameter and $5 \mathrm{~mm}$ length) and a commercial CNT (Nanocyl 3100, with an average diameter of $9.5 \mathrm{~nm}$, an average length of $1.5 \mathrm{~mm}$ with carbon purity higher than 95\%). The characteristics of those materials were previously reported (Pereira et al., 2010, 2014, 2016; Tessonnier et al., 2009) and are given in supplementary information (Tables S1 and S2). In order to prepare AC with different sizes, granular $(0.3<\mathrm{d}<0.6 \mathrm{~mm})$ or powder AC $(<0.25 \mathrm{~mm})$, the pellets were crushed and sieved. AO10 (dye content of $90 \%$ ) and aniline (99\%) were purchased from Sigma and used without additional purification. The real effluent was collect after the dyeing process from a textile company located in the north of Portugal, Valintece SA. The effluent was composed of the reactive azo dyes Remazol Blue RR, Remazol Brilliant Yellow and Remazol Yellow RR. Salts and detergents, softeners, surfactants and sizing, coating and finishing additives were also present. The exact composition of the effluent was not provided. This effluent was previously characterized in terms of colour, $\mathrm{pH}, \mathrm{COD}, \mathrm{SO}_{4}^{2-}, \mathrm{NO}_{3}^{2-}$, $\mathrm{NO}_{2}^{-}$and conductivity (Da Motta et al., 2014). The chemicals used to prepare the nutrients and substrate solutions were purchase from Sigma or Fluka at highest analytic grade purity commercially available. The solvent acetonitrile (ACN) and ammonium acetate for HPLC analysis were purchased from Acros and Panreac, respectively.

\subsection{UASB reactors operation}

The lab scale UASB reactors, made of acrylic glass and having a work volume of $400 \mathrm{~mL}(\mathrm{~L}=98 \mathrm{~cm}$; $\mathrm{d}=2 \mathrm{~cm})$. The reactors were seeded with $10 \mathrm{~g} \mathrm{~L}^{-1}$ of VS of anaerobic granular sludge obtained from a full-scale UASB reactor treating brewery wastes (Central de Cervejas, Portugal). Three reactors were operated: one with $A C$ (RAC), other with CNT (RCNT) and a third without CM (R0). The reactors were feed with a synthetic wastewater containing $0.50 \mathrm{mmol} \mathrm{L}^{-1}$ of $\mathrm{AO} 10$ and basal nutrients. The solution of micronutrients was composed of $2 \mathrm{~g} \mathrm{~L}^{-1} \mathrm{FeCl}_{2} \cdot 6 \mathrm{H}_{2} \mathrm{O} ; 0.05 \mathrm{~g} \mathrm{~L}^{-1}$ $\mathrm{H}_{3} \mathrm{BO}_{3} ; 0.05 \mathrm{~g} \mathrm{~L}^{-1} \mathrm{ZnCl}_{2} ; 0.038 \mathrm{~g} \mathrm{~L}^{-1} \mathrm{CuCl}_{2} \cdot 2 \mathrm{H}_{2} \mathrm{O} ; 0.5 \mathrm{~g} \mathrm{~L}^{-1}$ $\mathrm{MnCl}_{2} \cdot 4 \mathrm{H}_{2} \mathrm{O} ; \quad 0.05 \mathrm{~g} \mathrm{~L} \mathrm{~L}^{-1}\left(\mathrm{NH}_{4}\right)_{6} \mathrm{Mo}_{7} \mathrm{O}_{24} \cdot 4 \mathrm{H}_{2} \mathrm{O} ; 0.09 \mathrm{~g} \mathrm{~L}^{-1}$ $\mathrm{AlCl}_{3} \cdot 6 \mathrm{H}_{2} \mathrm{O} ; 2 \mathrm{~g} \mathrm{~L}^{-1} \mathrm{CoCl}_{2} \cdot 6 \mathrm{H}_{2} \mathrm{O} ; 0.092 \mathrm{~g} \mathrm{~L}^{-1} \mathrm{NiCl}_{2} \cdot 6 \mathrm{H}_{2} \mathrm{O}$ and $0.164 \mathrm{~g} \mathrm{~L}^{-1} \mathrm{Na}_{2} \mathrm{SeO}_{3} \cdot 5 \mathrm{H}_{2} \mathrm{O}$ (Zehnder et al., 1980) and the solution of macronutrients of $30 \mathrm{~g} \mathrm{~L}^{-1} \mathrm{MgSO}_{4} \cdot 7 \mathrm{H}_{2} \mathrm{O} ; 28.3 \mathrm{~g} \mathrm{~L}^{-1} \mathrm{KH}_{2} \mathrm{PO}_{4}$ and $170 \mathrm{~g} \mathrm{~L}^{-1} \mathrm{NH}_{4} \mathrm{Cl}$. Micronutrients were supplemented to the influent feed by addition of $1 \mathrm{~mL}$ per litre of feed and macronutrients by addition of $0.6 \mathrm{~mL}$ of the solution per gram of COD fed.

A mixture of $2 \mathrm{~g} \mathrm{~L}^{-1}$ of VFA at 1:10:10 COD ratio of acetate, propionate and butyrate, was added as the primary electron donor in order to provide the reducing equivalents for the reduction and the cleavage of the azo chromophore. This solution was refrigerated at $4{ }^{\circ} \mathrm{C}$ and fed to the reactor with a peristaltic pump. An internal recycle was made by a second peristaltic pump with a constant flow rate of $100 \mathrm{~mL} \mathrm{~min}{ }^{-1}$. Operating temperature was set at $(37 \pm 2){ }^{\circ} \mathrm{C}$ by circulating water through an external water jacket. The variables under study were CM concentrations ( 0.06 or $0.12 \mathrm{~g}$ per $\mathrm{g} \mathrm{VS}-0.6$ and $1.2 \mathrm{~g} \mathrm{~L}^{-1}$, respectively), CM size (granular or powder) and reactor HRT $(5,10$ or $20 \mathrm{~h}$ ) (Table 1$)$. RAC was operated at phases I to VI and RCNT at phases V and VI, with AO10, and at phase I' with the real effluent. R0 was operated at all phases (Table 1). Aniline was also feed to RAC at the concentration of $0.5 \mathrm{mmol} \mathrm{L}^{-1}$ in the conditions of phase $\mathrm{V}\left(\mathrm{RAC}_{\mathrm{AN}}\right)$ aiming at evaluating if the aniline formed from AO10 reduction, could be further bio reduced.

In order to replace the various CM, the UASB was stopped and the medium removed, so the previous material was separated from the medium with a sieve. As granular biomass has higher size than AC or CNT, remains in the sieve and the CM pass through it. UASB reactor was then filled again with the biomass and the new CM was added. In order to verify if the amount of CM was maintained constant, when AC was added in pellets, it was confirmed by counting the few number of pellets; when CM were added in powder, it was verified by visual inspection of the effluent collected and, additionally, by separating and weighing the possible fraction of CM that was washed out. With this procedure, it was verified that no $\mathrm{CM}$ were washed out from the reactor during the operation.

\subsection{Routine analysis}

Samples were withdrawn from the bioreactors every $24 \mathrm{~h}$, centrifuged and diluted up to an absorbance of less than 1, with a freshly solution of ascorbic acid $\left(200 \mathrm{mg} \mathrm{L}^{-1}\right)$ to prevent aromatic amines oxidation. AO10 decolourisation was followed by measuring the absorbance at the dye wavelength of maximum absorbance, $480 \mathrm{~nm}$, in a 96-well plate reader (ELISA BIO-TEK, Izasa) and converted to concentration with the molar extinction coefficient of the dye $\left(\varepsilon_{480 \mathrm{~nm}}=24.56 \mathrm{mmol} \mathrm{L} \mathrm{L}^{-1} \mathrm{~cm}^{-1}\right)$. Dye reduction was confirmed by HPLC in an Ultra HPLC (Shimadzu Nexera XZ) equipped with a diode array detector (SPD-M20A), autosampler (SIL-30AC), degassing (DGU-20A5R) and LC -30AD, and a Labsolutions software. A RP-18 endcapped Purospher Star column $(250 \mathrm{~mm} \times 4 \mathrm{~mm}, 5 \mu \mathrm{m}$ particle size, from MERCK, Germany) was used. Mobile phase was composed of two solvents: $10 \mathrm{mM}$ ammonium acetate solution and ACN. Compounds were eluted at a flow rate of $0.8 \mathrm{~mL} \mathrm{~min}^{-1}$ at room temperature, with an increase from $0 \%$ to $95 \%$ of $\mathrm{ACN}$ over $25 \mathrm{~min}$ and followed by an isocratic gradient during $10 \mathrm{~min}$. Samples were monitored at 
Table 1

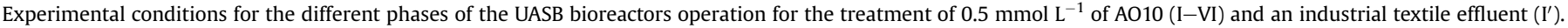

\begin{tabular}{|c|c|c|c|c|c|c|c|}
\hline Operation phase & I & II & III & IV & $\mathrm{V}$ & $\mathrm{VI}$ & $\mathrm{I}^{\prime}$ \\
\hline Days (d) & $1-9$ & $10-36$ & $37-61$ & $61-67$ & $68-77$ & $78-89$ & $1-15$ \\
\hline HRT (h) & 10 & 10 & 20 & 10 & 10 & 5 & 10 \\
\hline \multicolumn{8}{|l|}{ Carbon materials } \\
\hline type & AC & & & & AC; CNT & & CNT \\
\hline Concentration ( $\mathrm{g}$ of $\mathrm{CM}$ per $\mathrm{g}$ of $\mathrm{VS}$ ) & 0.06 & 0.12 & & & & & \\
\hline size $(\mathrm{mm})$ & 0.60 & & & $<0.25$ & & & \\
\hline
\end{tabular}

$480 \mathrm{~nm}$, for dye, and at $230 \mathrm{~nm}$, for aromatic amines identification. VS were determined according to standard methods (APHA et al., 1998). VFAs consumption was determined by HPLC (Jasco, Japan) equipped with a UV detector $(210 \mathrm{~nm})$ and a Rezex ${ }^{\mathrm{TM}}$ ion-exclusion column (Rezex ROA - organic acid $\mathrm{H}^{+}, 8 \%, 300 \times 7.8 \mathrm{~mm}$ ) at $60{ }^{\circ} \mathrm{C}$. Sulfuric acid $(0.01 \mathrm{~N})$ was used as mobile phase, at a flow rate of $0.6 \mathrm{~mL} \mathrm{~min}^{-1}$.

COD was determined using a standard kit (Hach Lange, Düsseldorf, Germany). The $\mathrm{pH}$ was measured with an HANNA HI 83141 $\mathrm{pH}$ meter (Germany). The $\mathrm{pH}$ was constant over the entire reactors operation, $\sim 7.4 \pm 0.2$, indicating a good stability of the process.

\subsection{Microbial community analyses}

Biomass samples were collected from R0 and RAC at operation phase $\mathrm{V}$, frozen and stored at $-20^{\circ} \mathrm{C}$ until DNA extraction. DNA was isolated using FastDNA Spin kit for soil (MP Biomedicals, USA) according to the manufacturer's instructions. Microbial communities' composition was determined by sequencing variable regions (V3 and V4) of the 16S rRNA gene. For that propose specific primer sets for the amplification of bacterial (Bakt_341F/Bakt_805R) and archaeal (Arch349F/Arch806R) domains were used (Table S3, supplementary information). Amplification, library preparation and sequencing by using an Illumina MiSeq sequencer, as well as taxonomic assignment of 16S rRNA reads (by using SILVA as reference database) were performed by Macrogen (Macrogen Inc., Republic of Korea). Illumina sequencing data was submitted to the European Nucleotide Archive (ENA), under the study accession number PRJEB12815, and can be viewed by following the URL: http://www.ebi.ac.uk/ena/data/view/ERP014332.

\section{Results and discussion}

\subsection{Reduction of AO10 in the UASB system}

The results of AO10 colour removal and COD at the different phases of the UASB reactor operation are presented in Table 2 and also in supplementary data, Fig. 1SA. In phase I, at an HRT of $10 \mathrm{~h}$ and $0.06 \mathrm{~g}$ of granular AC per $\mathrm{g}$ of VS $\left(0.6 \mathrm{~g} \mathrm{~L}^{-1}\right)$, colour removal was similar in both reactors and was lower than $30 \%$ (Table 2). The increase in AC concentration to $0.12 \mathrm{~g} \mathrm{~L}^{-1}$ in phase II, significantly increased the colour removal to $60 \%$, while in R0, decolourisation was kept near 20\%. A010 decolourisation increased in both reactors: $80 \%$ in RAC and 50\% in R0, in phase III, when the HRT was duplicated to $20 \mathrm{~h}$. Some studies also reported an increase in colour removal efficiency with the increase of the HRT (Isik and Sponza, 2004; Kapdan and Alparslan, 2005; Muda et al., 2011), because of the extended contact time between the biomass and the dye. Nevertheless, when the conditions of phase II were retaken, at phase IV, the percentage of AO10 decolourisation decreased to values near to the ones previously obtained in phase II. This result suggests that the higher decolourisation obtained in R0 at HRT of $20 \mathrm{~h}$ was due to the longer contact time rather than to the biomass adaptation to the dye, and demonstrates that, in the non-mediated bioreactors, the biological reduction of $\mathrm{AO} 10$ is a slow process, requiring longer hydraulic retention times. In phase $\mathrm{V}$, granular $\mathrm{AC}$ was replaced by powder AC, thus increasing the available surface are of the RM, and the percentage of $\mathrm{AO} 10$ reduction in RAC reached $96 \%$. This high percentage was constant over the entire period of reactor operation in these conditions, proving that powder AC, despite the lower density as compared with granular AC, could be retained inside the reactor. Retention of $\mathrm{CM}$ was previously assessed, by performing hydraulic tests at up-flow velocity in the range of $0.05-2.0 \mathrm{~m} \mathrm{~h}^{-1}$; effluent was collected and screened for the presence of $\mathrm{CM}$. In parallel, a third reactor containing the same amount of powder CNT, $0.12 \mathrm{~g}$ per $\mathrm{g}$ of VS also with $\mathrm{d}<0.25 \mathrm{~mm}$, was operated in the same conditions of phase $\mathrm{V}$ for AC. The percentage of decolourisation with CNT was $(98 \pm 1) \%$. As the application of $\mathrm{CM}$ aims to accelerate the reduction reactions, which was proved in previous reactor operation phases, in phase VI, the HRT was decreased to $5 \mathrm{~h}$. In the reactor with CNT the percentage of AO10 decolourisation was constant and circa $98 \%$, while with AC it decreased to $90 \%$. In a previous work, in batch assays, the efficiency of AC and CNT was evaluated as RM on the anaerobic biological decolourisation of different azo dyes (Pereira et al., 2010, 2014). The presence of CM was a requisite for biodegradation of AO10 and better results were obtained for the CM having larger pores, CNT (Pereira et al., 2014). In $5 \mathrm{~h}$ of reaction, the extent was $(45 \pm 8) \%$ increasing to $(98 \pm 2) \%$ within $24 \mathrm{~h}$. The better performance of the mesoporous $\mathrm{CM}$ was explained by the easier access of the dye molecules to the surface of the catalyst. Moreover, CNT are characterized by lower oxygen-containing surface groups and high amount of delocalized $\pi$ electrons on the surface which will be easily transferred.

Azo dye reduction in UASB bioreactors without RM has been reported by other authors, however, higher HRT were required and

Table 2

Average decolourisation and COD removal obtained at each phase in the UASB reactors.

\begin{tabular}{|c|c|c|c|c|c|c|c|c|}
\hline & Operation phase & I & II & III & IV & $\mathrm{V}$ & VI & $\mathrm{I}^{\prime}$ \\
\hline \multirow[t]{2}{*}{ R0 } & Decolourisation (\%) & $22 \pm 4$ & $18 \pm 5$ & $52 \pm 4$ & $28 \pm 3$ & $23 \pm 5$ & $16 \pm 4$ & $31 \pm 2$ \\
\hline & COD removal (\%) & $68 \pm 10$ & $71 \pm 7$ & $86 \pm 2$ & $82 \pm 3$ & $79 \pm 5$ & $80 \pm 3$ & $85 \pm 1$ \\
\hline \multirow[t]{2}{*}{ RAC } & Decolourisation (\%) & $28 \pm 6$ & $60 \pm 3$ & $73 \pm 3$ & $63 \pm 3$ & $98 \pm 1$ & $90 \pm 2$ & n.a \\
\hline & COD removal (\%) & $79 \pm 6$ & $79 \pm 6$ & $85 \pm 1$ & $85 \pm 1$ & $84 \pm 2$ & $81 \pm 3$ & \\
\hline \multirow[t]{2}{*}{ RCNT } & Decolourisation (\%) & n.a & n.a & n.a & n.a & $98 \pm 1$ & $98 \pm 3$ & $65 \pm 2$ \\
\hline & COD removal (\%) & & & & & $85 \pm 1$ & $81 \pm 3$ & $89 \pm 1$ \\
\hline
\end{tabular}


the process was effective only after long times of biomass acclimation (Donlon et al., 1997; Razo-Flores et al., 1997). Also the amount of dye used in this study, $0.5 \mathrm{mmol} \mathrm{L}^{-1}$, was much higher than the dye concentrations tested by other authors. Concerning the application of RM, most of the studies report batch assays, though some also describe the use of continuous reactors amended with $\mathrm{CM}$, although the amount of $\mathrm{CM}$ was higher circa 8 to 80 times higher than the used in this work (Table S4). As example, Mezohegyi et al. (2007, 2008) have used a small scale continuous reactor (upflow packed-bed) for the decolourisation of the azo dye Acid Orange 7 (AO7). The reactor was made of a plastic syringe of $10 \mathrm{~mL}$, filled with $10 \mathrm{~g}$ of inert carbon granules and $1 \mathrm{~g}$ of $\mathrm{AC}$ with size of 25-50 mesh. Besides the very high concentration of AC used $\left(100 \mathrm{~g} \mathrm{~L}^{-1}\right)$ and the little volume of the reactor, problems of clogging were reported due to the biomass growth in the packed bed. Van der Zee et al. (2003) have used AC as RM for the reduction of a recalcitrant azo dye (hydrolyzed Reactive Red 2, RR2) in an UASB of $250 \mathrm{~mL}$, using VFA as electron donor. In the absence of AC, RR2 decolourisation was $35 \%$, but when $\mathrm{AC}$ was present at the amount of $\mathrm{AC}, 10 \mathrm{~g} \mathrm{~L}^{-1}$, reduction was above $90 \%$. However, decreasing the AC concentration to $0.4 \mathrm{~g} \mathrm{~L}^{-1}$, RR2 decolourisation decreased to $40 \%$, in part due to exhaustion of dye adsorption on AC and AC washout from bioreactor. This author did not assess the changes in microbial diversity and obtained significant reduction with a concentration of $A C$ about 8 times higher than the ones used in our work. More recently, Amezquita-Garcia et al. (2016) immobilized activated carbon fibers (ACFs) in UASB reactors for the biological reduction of 4-nitrophenol (4NP). UASB reactors were packed with 12 polyvinyl chloride (PVC) disks where the ACFs were fixed. ACFs served as a support media for the growing of anaerobic microorganisms, but also as RM in the bioreduction of 4NP. At the beginning of the process, in the reactors with the disks, desorption of 4NP from the disks previously saturated has occurred and, then, adsorption/desorption processes were present until the equilibrium was reached, after 6-7 days. Biotransformation of 4NP was improved from $81 \%$, in the control reactor, to $>94 \%$, in reactor with ACFs.

The application of CM here demonstrated, opens prospects for an efficient treatment of high coloured baths at low HRT and with unadapted biomass. In addition, this is the first report applying mesoporous materials, CNT, which have been previously reported as advantageous when treating higher molecular weight molecules, including azo dyes (Pereira et al., 2014). Viewing this, R0 and RCNT were operated with fresh unadapted biomass to treat a real effluent, in phase I'. Colour removal in RCNT was the double, $(65 \pm 2) \%$, of the obtained in R0, $(31 \pm 2) \%$, (Table 2$)$. In terms of COD, circa $90 \%$ removal was obtained in both reactors.

Samples from influent and effluent, at increasing time intervals, of both reactors were analysed by HPLC aiming at identifying the reduction products of $\mathrm{AO} 10$ biological decolourisation on the UASB reactors. At $480 \mathrm{~nm}$, one peak at a retention time $\left(R_{t}\right)$ of 9.6 min was observed in the chromatogram of the influent sample, corresponding to AO10 (Fig. 1A). In phase V and VI, in the effluent of reactors containing $A C$ or CNT this peak was at very low intensity,

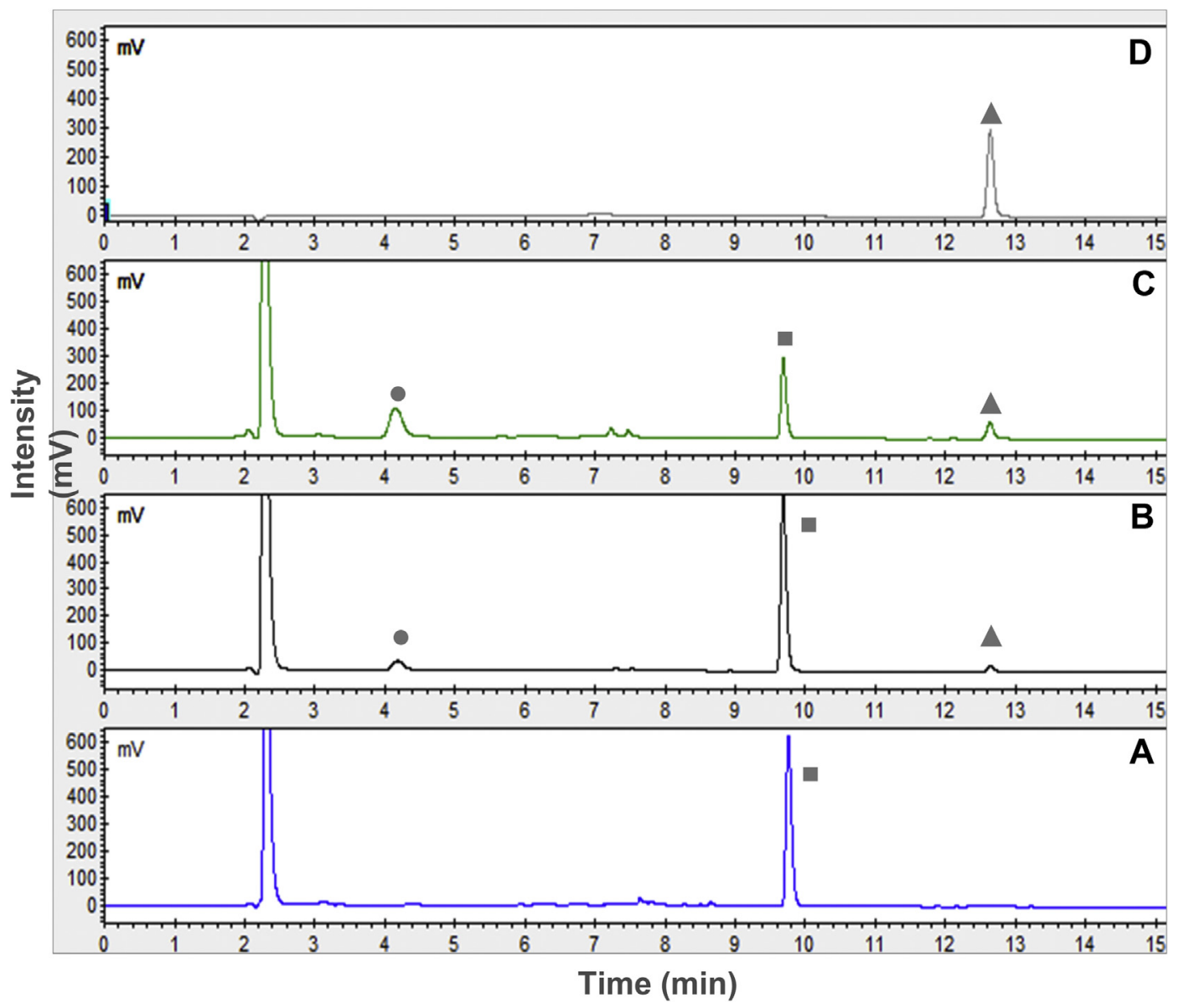

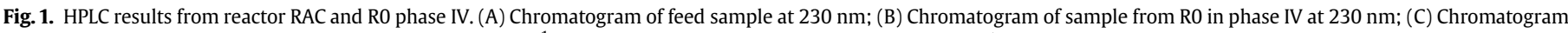

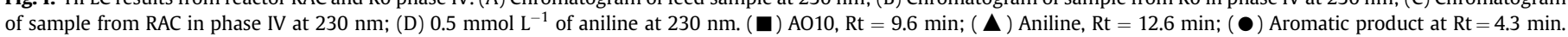




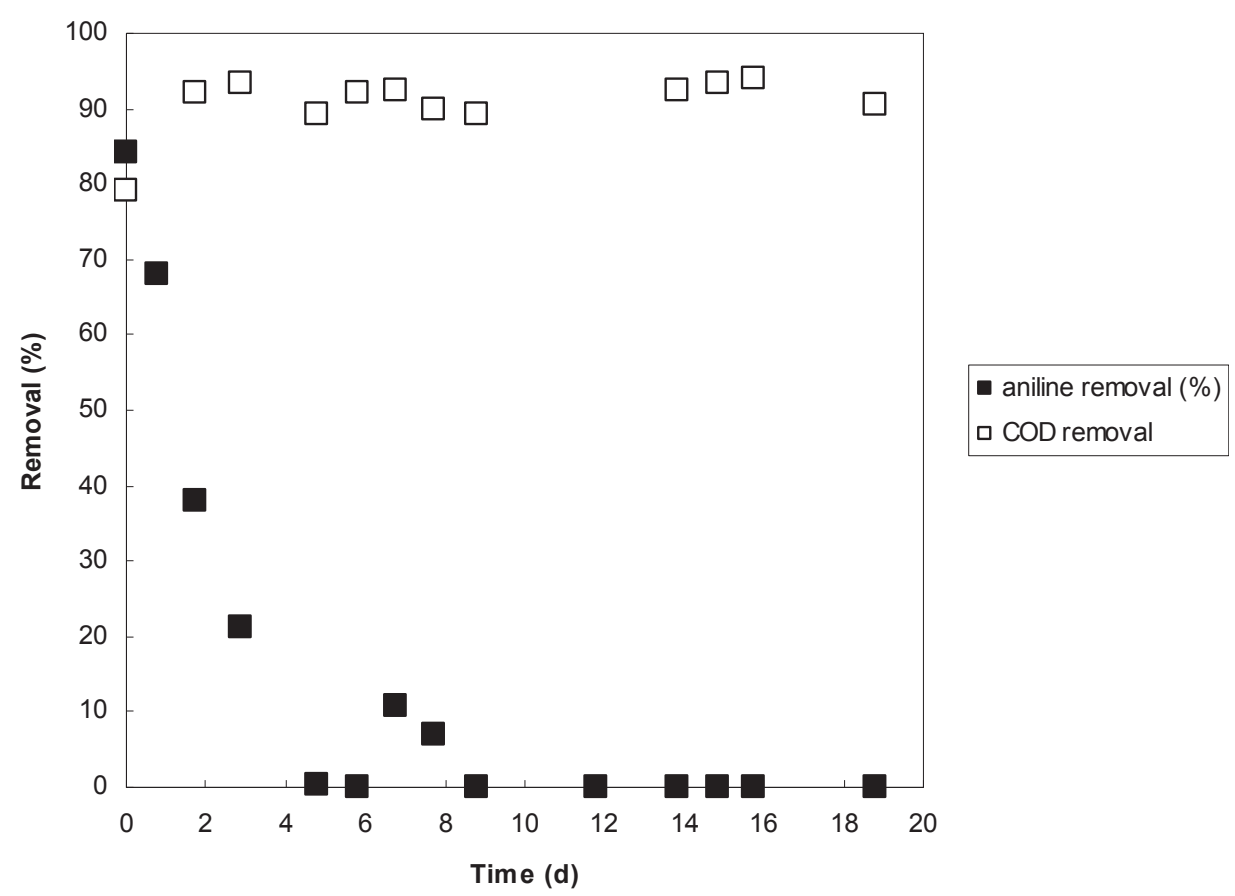

Fig. 2. Percentage of aniline ( $\square)$ and COD ( $\square$ ) removal in the $\operatorname{RAC}_{\mathrm{AN}}$ operated with an HRT of $10 \mathrm{~h}$.
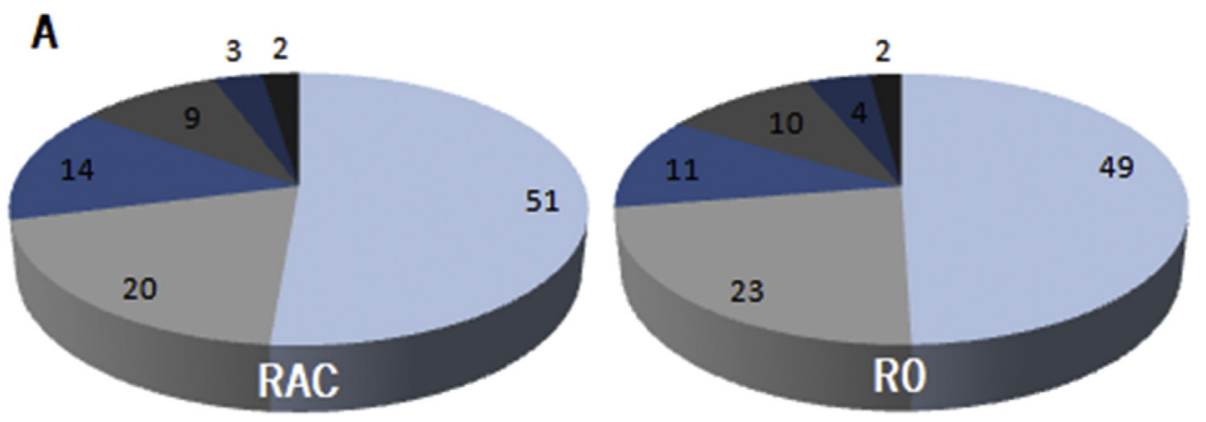

" Methanosaeta

- Methanobacterium

- Methanospirillum

- Methanolinea

- Candidatus Methanoregula

- Unknown
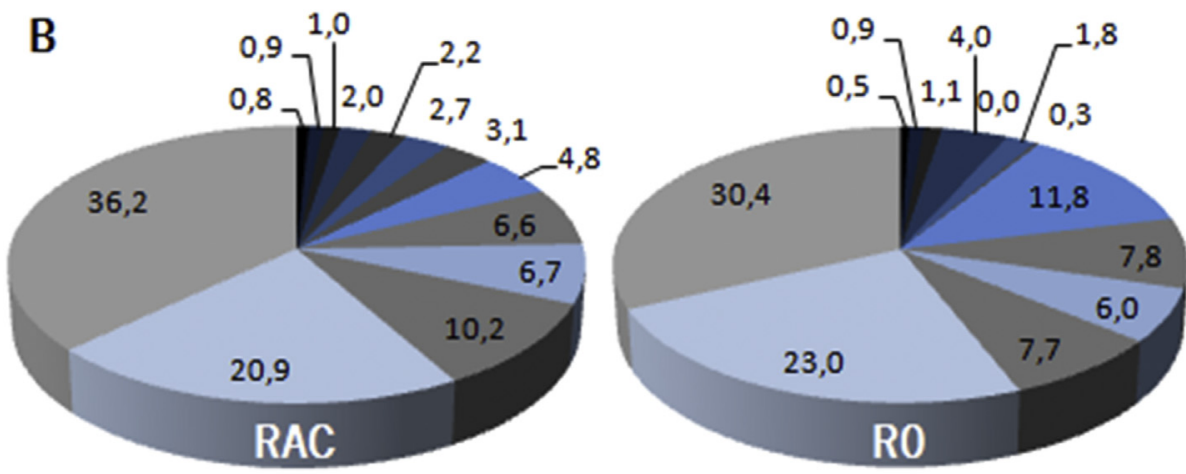

- Desulfobulbus

- Syntrophus

- Syntrophorhabdus

- Delftia

- Acinetobacter

- Kosmotoga

- Azovibrio

- Syntrophomonas

- Pseudomonas

Geobacter

- Nitrospira

- Syntrophobacter

Unknown

Fig. 3. Distribution of $16 \mathrm{~S}$ rRNA genes sequences among Bacteria (A) and Archaea (B) superkingdoms. 
confirming the high colour removal ( 98\%). As monitored at $230 \mathrm{~nm}$, two new peaks at $\mathrm{R}_{\mathrm{t}}$ of 4.3 and 12.6 min were present (Fig. 1B and C). The peak at Rt $12.6 \mathrm{~min}$, as compared with the standard (Fig. 1D), was assigned to aniline, proving that the azo dye linkage was broken and that decolourisation in mediated bioreactors occurred due to biological activity and not to adsorption onto $\mathrm{CM}$. The other peak may match the other correspondent aromatic amine (8-amino-7-hydroxynaphthalene-1,3disodiumsulfonate). Aniline was recovered in the effluent at a yield of $(99 \pm 16) \%$, revealing that it is not further degraded under the process conditions, which was also proved by feeding the RAC with a solution containing $0.5 \mathrm{mmol} \mathrm{L}^{-1}$ of aniline (Fig. 2). In the first days, the high levels of aniline removal were likely due to adsorption on AC, declining to zero, after 4 days. The high COD removal ( $>90 \%$ ) reveals that biological activity is not affected by the presence of aniline. Biological degradation of aromatic amines under anaerobic conditions is a difficult process. Only a few, carrying hydroxyl or carboxyl groups, were found to be degraded (Kalyuzhnyi and Skyler, 2000; Razo-Flores et al., 1999). For an effective azo dye degradation process, aromatic amines should be further degraded (Van der Zee and Villaverde, 2005), for example under aerobic conditions (Barsing et al., 2011; Brown and Laboureur, 1983; Tan et al., 1999, 2005) or denitrifying conditions (Pereira et al., 2010). These later conditions are advantageous to prevent the auto oxidation that occurs in the presence of oxygen.

Regarding the COD removal, good removal efficiency was obtained in all phases, $70 \%$ in R0 and $~ 80 \%$ in RAC, at phases I and II, and above $80 \%$ in the following phases of the three reactors (Fig. 1SB). COD removal was independent of colour removal, suggesting that the dye was not toxic to the granular sludge used in the reactors. This was already suggested previously when a toxicity assay of the azo dye in the range of concentrations of 0.125-4 $\mathrm{mmol} \mathrm{L}^{-1}$ was performed (Pereira et al., 2014).

\subsection{Microbial communities in UASB reactors treating $A O 10$}

Microbial communities present in R0 and RAC are diverse as determined by $16 \mathrm{~S}$ rRNA genes sequencing (Fig. 3). No major differences were detected between the bacterial and archaeal communities developed in R0 and RAC (Fig. 3). According to the obtained results, AC did not cause a shift on the composition of microbial communities, suggesting that colour removal in RAC was not due to proliferation of certain groups of microorganisms, but was mainly due to the electron shuttle effect of AC. Most abundant microorganisms belong to genera Syntrophobacter, Nitrospira, Geobacter, Pseudomonas, Syntrophomonas, and also to unknown Bacteria (which represent over $30 \%$ of the total sequences obtained from both reactors) (Fig. 3). Microorganisms belonging to Geobacter and Pseudomonas genera were reported to be involved in azo dyes reduction (Khehra et al., 2005; Liu et al., 2013). In this work, about $7 \%$ of the total bacterial sequences were assigned to each one of the former genera suggesting that those microorganisms might have a role on decolourisation during the bioreactors operation. The high microbial diversity detected in both reactors should be highly determined by the electron and carbon donors, i.e, VFAs. Several bacterial groups such as, Syntrophobacter and Syntrophomonas (23\% and $13 \%$ in R0, respectively, $21 \%$ and $5 \%$ in reactor RAC, respectively) are well known syntrophic VFAs oxidizers (Harmsen et al., 1998; Lorowitz et al., 1989; Plugge et al., 2012; Wu et al., 2006), contributing for VFAs conversion to methane together with acetoclastic and hydrogenotrophic methanogens. Methanogenic archaea were also identified in this study, being the acetate consumer, Methanosaeta, the most abundant methanogen (with circa $50 \%$ of total archaeal sequences assigned) (Fig. 3). Diversity of hydrogenotrophic methanogens was higher and sequences were assigned to Methanobacterium (23\% and 20\% for R0 and RAC respectively), Methanospirillum ( $11 \%$ and $14 \%$ for R0 and RAC respectively), Methanolinea (10\% and 9\% for R0 and RAC respectively) and Methanoregula (4\% and 3\% for R0 and RAC respectively) genera.

\section{Conclusions}

The results here presented clearly demonstrate that AC and CNT, at a concentration as low as $1.2 \mathrm{~g} \mathrm{~L}^{-1}$ within the sludge bed of an UASB reactors, improved significantly the efficiency of biological reduction of $\mathrm{AO} 10$ to the correspondent aromatic amines. 98\% of colour and $85 \%$ of COD removal were obtained in the UASB reactor amended with $0.12 \mathrm{~g}$ of CNT per $\mathrm{g}$ of VS (with an HRT of $5 \mathrm{~h}$ ). The size of CM was an important factor and higher AO10 decolourisation was achieved with powder $\mathrm{CM}$, due to its higher available surface area. Biological decolourisation of AO10 was about 20\% in the absence of RM, in all phases, except at the HRT of $20 \mathrm{~h}$, where it reached $52 \%$. The presence of CNT in a bioreactor treating an industrial textile effluent also improves colour removal from $30 \%$ to $65 \%$. COD removal was similar in both cases. The presence of AC did not affect the microbial diversity, suggesting that the higher colour removal was due to the capacity of AC to act as RM or catalyst, decreasing the activation energy of the electron transfer from the VFA to the azo bond.

\section{Acknowledgment}

This study was supported by the Portuguese Foundation for Science and Technology (FCT) under the scope of the strategic funding of UID/BIO/04469/2013 unit and COMPETE 2020 (POCI-010145-FEDER-006684). Raquel Pereira had a fellowship (SFRH/BD/ 72388/2010) and Luciana Pereira has the fellowship (SFRH/BPD/ 110235/2015) from FCT. The authors thank the FCT exploratory EXPL/AAG-TEC/0898/2013 project.

\section{Appendix A. Supplementary data}

Supplementary data related to this article can be found at http:// dx.doi.org/10.1016/j.watres.2016.06.004.

\section{References}

Amezquita-Garcia, H.J., Razo-Flores, E., Cervantes, F.J., Rangel-Mendez, J.R., 2013 Activated carbon fibers as redox mediators for the increased reduction of nitroaromatics. Carbon 555, 276-284. http://dx.doi.org/10.1016/ j.carbon.2012.12.062.

Amezquita-Garcia, H.J., Rangel-Mendez, J.R., Cervantes, F.J., Razo-Flores, E., 2016. Activated carbon fibers with redox-active functionalities improves the continuous anaerobic biotransformation of 4-nitrophenol. Chem. Eng. J. 286, 208-215. http://dx.doi.org/10.1016/j.cej.2015.10.085.

APHA, AWWA, WPCF, 1998. Standard Methods for the Examination of Water and Wastewater, seventeenth ed. American Public Health Association, Washington, D.C.

Barsing, P., Tiwari, A., Joshi, T., Garg, S., 2011. Application of a novel bacterial consortium for mineralization of sulphonated aromatic amines. Bioresour. Technol. 102, 765-771. http://dx.doi.org/10.1016/j.biortech.2010.08.098.

Bragger, J.L., Lloyd, A.W., Soozandehfar, S.H., Bloomfield, S.F., Marriott, C., Martin, G.P., 1997. Investigations into the azo reducing activity of a common colonic microorganism. Int. J. Pharm. 157 (1), 61-71. http://dx.doi.org/10.1016/ S0378-5173(97)00214-7.

Brown, D., Laboureur, P., 1983. The aerobic biodegradability of primary aromatic amines. Chemosphere 12, 405-414. http://dx.doi.org/10.1016/0045-6535(83) 90115-7.

Colunga, A., Rangel-Mendez, J.R., Celis, L.B., Cervantes, F.J., 2015. Graphene oxide as electron shuttle for increased redox conversion of contaminants under methanogenic and sulfate-reducing conditions. Bioresour. Technol. 175, 309-314. http://dx.doi.org/10.1016/j.biortech.2014.10.101.

Da Motta, M., Pereira, R., Alves, M.M., Pereira, L., 2014. UV/TiO 2 photocatalytic reactor for real textile wastewaters treatment. Water Sci. Technol. 70 (10), 1670-1676. http://dx.doi.org/10.2166/wst.2014.428. 
Donlon, B., Razo-Flores, E., Luijten, M., Swarts, H., Lettinga, G., Field, J., 1997. Detoxification and partial mineralization of the azo dye mordant orange 1 in a continuous upflow anaerobic sludge-blanket reactor. Appl. Microbiol. Biotechnol. 47, 83-90. http://dx.doi.org/10.1007/s002530050893.

Herzberg, M., Dosoretz, C.G., Tarre, S., Beliavski, M., Green, M., 2004. Biological granulated activated carbon fluidized bed reactor for atrazine remediation. Water Sci. Technol. 49 (11-12), 215-222.

Harmsen, H.J., Van Kuijk, B.L., Plugge, C.M., Akkermans, A.D., De Vos, W.M., Stams, A.J., 1998. Syntrophobacter furnaroxidans sp. nov., a syntrophic propionate-degrading sulfate reducing bacterium. Int. J. Syst. Bacteriol. 48, 1383-1387.

Isik, M., Sponza, D.T., 2004. Anaerobic/aerobic sequential treatment of a cotton textile mill wastewater. J. Chem. Technol. Biotechnol. 79, 1268-1274. http:// dx.doi.org/10.1002/jctb.1122.

Kalyuzhnyi, S., Skyler, V., 2000. Biomineralisation of azo dyes and their breakdown products in anaerobic-aerobic hybrid and UASB reactors. Water Sci. Technol. 41, $23-30$.

Kapdan, I.K., Alparslan, S., 2005. Application of anaerobic-aerobic sequential treatment system to real textile wastewater for color and COD removal. Enzyme Microb. Technol. 36, 273-279. http://dx.doi.org/10.1016 j.enzmictec.2004.08.040.

Khehra, M.S., Saini, S.N., Sharma, D.K., Chadha, D.S., Chimni, S.S., 2005. Decolorization of various azo dyes by bacterial consortia. Dyes Pigments 67, 55-61. http://dx.doi.org/10.1016/j.dyepig.2004.10.008.

Lettinga, G., Vanvelsen, A.F.M., Hobina, S.M., Zee, W., Klapswik, A., 1980. Use of the Upflow sludge blanket (USB) reactor concept for biological wastewater treatment, especially for anaerobic treatment. Biotechnol. Bioeng. 22, 699-734. http://dx.doi.org/10.1002/bit.260220402.

Liu, F., Rotaru, A.E., Shrestha, P.M., Malvankar, N.S., Nevin, K.P., Lovley, D.R., 2012 Promoting direct interspecies electron transfer with activated carbon. Energy Environ. Sci. 5, 8982-8989. http://dx.doi.org/10.1039/C2EE22459C.

Liu, G., Zhou, J., Chen, C., Wang, J., Jin, R., Lv, H., 2013. Decolorization of azo dyes by Geobacter metallireducens. Appl. Microbiol. Biotechnol. 97 (17), 7935-7942. http://dx.doi.org/10.1007/s00253-012-4545-7.

Lorowitz, W.H., Zhao, H., Bryant, M.P., 1989. Syntrophomonas wolfei subsp. Saponavida subsp. Nov., a long-chain -fatty- acid-degrading, anaerobic, syntrophic bacterium; Syntrophomonas wolfei subsp. Wolfei subsp. Nov.; and emended descriptions of the genus and species. Int. J. Syst. Bacteriol. 122-126. http:// dx.doi.org/10.1099/00207713-39-2-122.

Marsh, H., Rodríguez-Reinoso, F., 2006. Activated Carbon, first ed. Elsevier, Oxford.

Mezohegyi, G., Kolodkin, A., Castro, U.I., Bengoa, C., Stuber, F., Font, J., Fabregat, A 2007. Effective anaerobic decolorization of azo dye acid orange 7 in continuous upflow packed-bed reactor using biological activated carbon system. Ind. Eng. Chem. Res. 46, 6788-6792. http://dx.doi.org/10.1021/ie061692o.

Mezohegyi, G., Bengoa, C., Stuber, F., Font, J., Fabregat, A., Fortuny, A., 2008. Novel bioreactor design for decolourisation of azo dye effluents. Chem. Eng. J. 143 (1-3), 293-298. http://dx.doi.org/10.1016/j.cej.2008.05.006.

Mezohegyi, G., Goncalves, F., Orfao, J.J.M., Fabregat, A., Fortuny, A., Font, J., Bengoa, C., Stuber, F., 2010. Tailored activated carbons as catalysts in biodecolourisation of textile azo dyes. Appl. Catal. B Environ. 94 (2010), 179-185. http://dx.doi.org/10.1016/j.apcatb.2009.11.007.

Moir, D., Masson, S., Chu, I., 2001. Structure-activity relationship study on the bioreduction of AZO dyes by Clostridium paraputrificum. Environ. Toxicol. Chem. 20 (3), 479-484. http://dx.doi.org/10.1002/etc.5620200304.

Muda, M., Aris, A., Salim, M.R., Ibrahim, Z., Van Loosdrecht, M.C.M., Ahmad, A Nawahwi, M.Z., 2011. The effect of hydraulic retention time on granular sludge biomass in treating textile wastewater. Water Res. 45, 4711-4721. http:// dx.doi.org/10.1016/j.watres.2011.05.012.

Pereira, L., Pereira, R., Pereira, M.F.R., Van der Zee, F.P., Cervantes, F.J., Alves, M.M. 2010. Thermal modification of activated carbon surface chemistry improves its capacity as redox mediator for azo dye reduction. J. Hazard. Mater. 183, 931-939. http://dx.doi.org/10.1016/j.jhazmat.2010.08.005.

Pereira, R., Pereira, M.F.R., Alves, M.M., Pereira, L., 2014. Carbon based materials as novel redox mediators for dye wastewater biodegradation. Appl. Catal. B Environ. 144, 713-720. http://dx.doi.org/10.1016/j.apcatb.2013.07.009.

Pereira, L., Pereira, R., Pereira, M.F., Alves, M.M., 2016. Effect of different carbon materials as electron shuttles in the anaerobic biotransformation of nitroanilines. Biotechnol. Bioeng. 113 (6), 1194-1202. http://dx.doi.org/10.1002/ bit.25896.

Plugge, C.M., Henstra, A.M., Worm, P., Swarts, D.C., Paulitsch-Fuchs, A.H., Scholten, J.C.M., Lykidis, A., Lapidus, A.L., Goltsman, E., Kim, E., McDonald, E., Rohlin, L., Crable, B.R., Gunsalus, R.P., Stams, A.J.M., McInerney, M.J., 2012. Complete genome sequence of Syntrophobacter fumaroxidans strain (MPOBT). Stand. Genomic Sci. 7, 91-106. http://dx.doi.org/10.4056/sigs.2996379.

Razo-Flores, E., Luijten, M., Donlon, B.A., Lettinga, G., Field, J.A., 1997. Complete biodegradation of the azo dye azodisalicylate under anaerobic conditions. Environ. Sci. Technol. 31 (7), 2098-2103. http://dx.doi.org/10.1021/es960933o.

Razo-Flores, E., Smulders, P., Prenafeta-Bold, F., Lettinga, G., Field, J.A., 1999. Treatment of anthranilic acid in an anaerobic expanded granular sludge bed reactor at low concentrations. Water Sci. Technol. 40, 187-194. http://dx.doi.org/ 10.1016/S0273-1223(99)00625-3.

Shaul, G.M., Barnett, M.W., Neiheisel, T.W., Dostal, K.A., 1983. Activated sludge with powdered activated carbon treatment of a dyes and pigments processing wastewater. In: Proceedings of the 38th Industrial Waste Conference, pp. 659-672.

Specchia, V., Gianetto, A., 1984. Powdered activated carbon in an activated sludge treatment plant. Water Res. 18 (2), 133-137. http://dx.doi.org/10.1016/00431354(84)90060-5.

Tan, N.C.G., Prenafeta-Boldú, F.X., Opsteeg, J.L., Lettinga, G., Field, J.A., 1999. Biodegradation of azo dyes in coculture of anaerobic granular sludge with aerobic aromatic amine degrading enrichment cultures. Appl. Microbiol. Biotechnol. 51 (6), 865-871. http://dx.doi.org/10.1007/s002530051475.

Tan, N.C.G., Van Leeuwen, A., Van Voorthuinzen, E.M., Slenders, P., PrenafetaBoldú, F.X., Temmink, H., Lettinga, G., Field, J.A., 2005. Fate and biodegradability of sulfonated aromatic amines. Biodegradation 16, 527-537.

Tessonnier, J.P., Rosenthal, D., Hansen, T.W., Hess, C., Schuster, M.E., Blume, R., Girgsdies, F., Pfänder, N., Timpe, O., Su, D.S., Schlögl, R., 2009. Analysis of the structure and chemical properties of some commercial carbon nanostructures. Carbon 47 (7), 1779-1798.

Van der Zee, F.P., Bisschops, I.A.E., Lettinga, G., Field, J.A., 2003. Activated carbon as an electron acceptor and redox mediator during the anaerobic biotransformation of azo dyes. Environ. Sci. Technol. 37, 402-408. http://dx.doi.org/10.1021/ es025885o.

Van der Zee, F.P., Villaverde, S., 2005. Combined anaerobic-aerobic treatment of azo dyes- A short review of bioreactors studies. Water Res. 39, 1425-1440. http:// dx.doi.org/10.1016/j.watres.2005.03.007.

Van der Zee, F.P., Cervantes, F.J., 2009. Impact and application of electron shuttles on the redox (bio)transformation of contaminants: a review. Biotechnol. Adv. 27, 256-277. http://dx.doi.org/10.1016/j.biotechadv.2009.01.004.

Wu, C., Liu, X., Dong, X., 2006. Syntrophomonas cellicola sp. nov., a spore-forming syntrophic bacterium isolated from a distilled-spirit-fermenting cellar, and assignment of Syntrophospora bryantii to Syntrophomonas bryantii comb. nov. Int. J. Syst. Evol. Microbiol. 56, 2331-2335. http://dx.doi.org/10.1099/ ijs.0.64377-0.

Xie, X., Criddle, C., Cui, Y., 2015. Design and fabrication of bioelectrodes for microbial bioelectrochemical systems. Energy Environ. Sci. 8, 3418. http://dx.doi.org/ 10.1039/C5EE01862E.

Zehnder, A.J.B., Huser, B.A., Brock, T.D., Wuhrmann, K., 1980. Characterization of an acetate-decarboxylating, non-hydrogen-oxidizing methane bacterium. Arch. Microbiol. 124, 1-11. http://dx.doi.org/10.1007/BF00407022. 